\title{
Research on the Relationship between the Local Government's Core Competence and Public Service Satisfaction
}

\author{
Yazhou Yu \\ Xi'an Institute of Finance and Economics Xingzhi school, Xi'an, Shaanxi, China, 710038
}

Keywords: local government's core competence and teaching mode; public service satisfaction

\begin{abstract}
The core competitiveness of government is changing from decision-making to public service. The management of the government has yet to be improved, especially on how to deal with the relationship with public organizations. Public service capability is the new direction of government competitiveness. This paper describes the characteristics of local government core competitiveness and public service satisfaction, and the functional mechanisms between the two, and analyzes in detail the path to enhance the local government's core competitiveness and public service satisfaction.
\end{abstract}

\section{Introduction}

In the process of the development of socialist market economy, the role of local governments in local economic and social development is indispensable. As the main body of the local interests, the local government can stand out in the competition and highlight its own advantages, which have become an important task for the government to strengthen its own construction at the present stage [1]. The competitiveness of the government is a unique core expertise of the government, and it is the incomparable ability accumulated by the government in the exercise of its administrative power to provide services to its citizens. This enables the local government to maintain its competitive advantage and obtain political stability. The government, just as enterprises, can only by establishing its own competitiveness so that to stand out in a fierce competitive environment and promote the all-round development of politics, economy, and culture in the areas under its jurisdiction, and play the full role of guiding the flow of various elements within the jurisdiction area. Public service competition is an extremely important form of government competition. It targets the public interest and is the driving force for the government to improve the quality of public services and meet public needs. The competitiveness of local government in public services is limited to a specific area, and by providing better and more effective public services than competitors, to enhance the satisfaction of local residents, companies, and social groups, and attracting the influx of high-quality, mobile elements, thus to maintain the government's stability and to enhance the realistic and potential ability of the government's charm and dominance.

\section{The Characteristics of Local Government Core Competence and Public Service Satisfaction}

\subsection{The overall status and characteristics of local government's core competitiveness}

At present, local governments have stronger innovation and routine management capabilities, but basic service capabilities and non-essential service capabilities in the areas of crisis management capabilities and service capabilities are significantly weaker than innovation and conventional management capabilities [2]. The local government has excellent ability in applying new technology to administrative management and innovation of social governance, but at the same time, non basic service capacity, basic public service capacity and crisis management ability need to be strengthened.

The local government has done a better job in the training of civil servants in business and professional ethics, with strong ability of daily affairs management. However, the local government's 
operational process capacity is not strong enough, and the public evaluation is not high. The ability of local government crisis management is mainly represented by issue pre-management, that is, various preventive measures before the crisis occur. However, government's ability to deal with the crisis is poor, and it is particularly difficult for government to deal with issues such as whether the crisis has been informed to the public, and how should be the public notified.

The basic public service ability of the local government is mainly reflected in its achievements in social security and education service. However, the imperfect infrastructure and the poor supervision of public security are still the weaknesses of the core competitiveness of the local government. Local governments have increased their guidance on non-essential public service areas and encouraged private capital to enter related fields. However, due to the lack of corresponding policy support and institutional support, local governments have not really take up their own roles in non-essential public service areas.

\subsection{The overall status and characteristics of public service satisfaction}

At present, the satisfaction of the public with respect to the effectiveness of cleanliness and the level of satisfaction with the service level have been significantly increased, but the degree of satisfaction with the performance of duties functions and satisfaction with public policies remains to be improved. The degree of satisfaction with the social security, health care, and service level of providing a clean social environment provided by the local government is relatively high. However, satisfaction with the quality of services such as food safety, environmental issues, and food issues that are closely related to life needs to be improved. The public is more satisfied with the reform of the household registration system, but there are still dissent and dissatisfaction with the reform of the current land circulation system. The degree of satisfaction with the government's maintenance of power and functioning is relatively high, but for basic government functions such as employment, income, and price control are not very satisfactory to the public.

\section{The Function Mechanism between Local Government Core Competence and Public Service Satisfaction}

There is a significant correlation between the local government core competitiveness and public service satisfaction. The local government core competitiveness has certain predictability for public service satisfaction, that is, the strength of local government competitiveness will affect the level of public service satisfaction [3]. Therefore, if we want to improve public service satisfaction, it should improve and strengthen the core competitiveness of local governments.

The ability of non-essential public services in the local government's core competitiveness has a predictive effect on the satisfaction of the clean performance in public satisfaction, indicating that local governments have fairly introduced market forces and provided corresponding policy support in special areas such as pensions and medical care, and providing the highest quality non-essential public services, the public's assessment of corruption of the government and its staff will directly affect the integrity of the local government, with the increase of public satisfaction, public recognition of local governments will also increase.

The basic public service ability and non-public service ability in the local government's core competitiveness have a significant predictive effect on the satisfaction level of the service level in the public satisfaction, which shows that the local government can boldly explore and innovate in a time of change, and this will definitely provide more convenient services for the people. The conventional management capability of the local government's core competitiveness has a significant predictive effect on the degree of fulfillment of job performance in public satisfaction, which shows that the conventional management capability is the government's most basic ability and represents the standard of the government's performance. Good general management capability must have a higher level of performance capacity.

Local governments with superb service capabilities, when facing emergence issues, such as sudden incidents, disaster accidents, group incidents, and so on, could properly dispose on time. If 
local governments can provide the public with comprehensive public services and public products, then the service capacity of local governments will be favored by the public, and service level satisfaction will increase.

The non-essential public service capabilities in the local government's core competitiveness have a significant predictive effect on public policy satisfaction in public satisfaction. Non-essential public services are mainly embodied in special fields and are the content of basic public services of local governments. Because of the special nature of non-essential public services, the strength of this ability has an important impact on the satisfaction of public policies.

\section{Measures to Improve Local Government Core Competence and Public Service Satisfaction}

\subsection{Enhance local government innovation capabilities}

Innovation is vital both for individuals and collectives. For the local government, especially the municipal government, it is not only the economic and cultural center of a certain region, but also the first level government of the administrative units, such as district, county and other administrative units. Its innovation ability is not only related to its own development, but also has a certain leading role for the governments at all levels under its jurisdiction. With the rapid development of science and technology, technological innovation and breakthroughs have completely changed the government's office and governance mode. However, in the background of this era, there are still some problems: from the theoretical perspective, if local governments want to serve the people and be trusted by the people, it is necessary to break through some thinking limits, to plan a new way of development, promote the development of practical innovation with the idea, and promote the public satisfaction with the development. From the perspective of technology application, although most local governments have implemented electronic office, e-government, there is no doubt that there are obvious deficiencies in the application of new technologies in social governance.

From a practical perspective, the old thinking model of local governments has been driving local governments to repeat the regional development model of closed and conservative, and local protectionism is prevalent. In order to seek local development, many regions reject the demand for resources such as land and labor in other regions by other regions. The new type of regional development is the development mode of regional cooperation. The core competitiveness of the government is not the tangible resources owned by the local government, but a new type of service and management model.

\subsection{Strengthen local government management capabilities}

The government management capabilities include conventional management capabilities and crisis management capabilities [4]. Good management capability will induce a higher degree of public satisfaction in performing duties, good crisis management capabilities will induce a certain level of service public satisfaction, and vice versa. It can thus be seen that the strengthening of the government's core competitiveness has a certain indicative effect on public satisfaction. To improve public satisfaction, it is necessary to strengthen the management capabilities of local governments and achieve breakthroughs from the local government's social governance model. The establishment of a crisis management and early warning plan system will enhance the government's crisis management capabilities. And change the backward government's one-way governance model and replace it with the public's extensive participation in the modern governance model, strengthen regional cooperation, to achieve a win-win governance mode.

\subsection{Raise the service awareness of local government}

According to Montesquieu's contractual spirit, the significance of the country's existence is to provide a safety and happiness living environment for the people. As far as modern national governments are concerned, education products, medical insurance, and infrastructure provided for the people are the basis for measuring the level of government services. The government should not 
only provide high-quality, adequate basic public services to the public, but also must fulfill its duty in non-essential public service areas that are derived from basic services. However, under the influence of the traditional official concept, some local governments and their staff have a natural sense of superiority. Not only have they smashed their sacred duties and powers, they have ignored the demands of the masses, and they also have ruthlessly ruling governance and low levels of governance, which will seriously hurt the people's feelings. According to the research data, the service capacity of local governments has a predictive effect on public satisfaction. Therefore, it is of great significance for local governments to improve their governance methods and upgrade their level of governance to enhance public service satisfaction.

\section{Summary}

The core competitiveness of local governments reflects the investment environment of a region, a city and the sense of happiness of the citizens. Under the background of globalization, competition among local governments and governments is in full swing. The subject of competition among governments has also gone from the previous hardware competition to the era of software competition. Enhancing the core competitiveness of local governments is not only the key to enhancing regional core strength, but also the key to improving public service satisfaction and building a service-oriented government. Therefore, the improvement of the local government's core capabilities in innovation, service, and management is of great significance to the development of the local government itself. And the strengthening of local government capabilities will inevitably increase public trust and level of satisfaction with the government.

\section{References}

[1] Peng Guoxuan, Liu Jing. Theoretical Basis and Realistic Demand of Public Satisfaction Measurement in Government Education Management[J]. Journal of Hunan University, 2012, (1), p.55

[2] Xiao Wentao, Cheng Yu. Research on Local Government Competitiveness Based on Scientific and Technological Innovation[J]. Administrative Forum, 2015S, (5), p.34

[3] Zou Kai. Theory, Method and Application of Community Service Public Satisfaction Assessment[D]. Doctoral Science, National University of Defense Technology, 2016, p.17

[4] Lu Weixia, Wang Yonggui. Research on the Mechanism of Public Perceived Administrative Service Quality to Government Reputation[J]. Journal of Renmin University of China, 2010, (4), p.117 